\title{
NATIONAL INDUSTRY 4.0 PLATFORMS IN THE VISEGRAD 4 COUNTRIES - A COMPARISON WITH THE FRONTRUNNER DIGITAL ECONOMIES IN EUROPE
}

\author{
Áron GYIMESI ${ }^{*}$ \\ Széchenyi University, Hungary
}

\begin{abstract}
Based on the international digitization indexes, the development level of digitalization in the Visegrad Four (V4) countries is similar in many respects. The status of the recent digital developments is comparable in results and in deficits also. These economies have similar inescapable paths in the past and further development opportunities in the future. The economic success of these four countries greatly depends on the transformation of their economic structures, mainly by utilizing digitalization. This study compares the approaches, activities and initiatives of the national Industry 4.0 platforms of the V4 countries that promote and support the digital transformation on the national strategic level. The study also highlights the results that have already been achieved by the members of the European Quartet. These four countries have reached good results in digital infrastructure investments. Meanwhile, they are left behind in skillsets, education and adoption of companies, regarding their digital transformation. Beside the direct comparison of the four Industry 4.0 platforms, the study extends the research to three of the Frontrunner countries of the EU in digitalization, namely to Austria, Germany, Sweden, to understand the best practices they use and actions they take regarding the digitalization. The paper formulates guidelines for defining competitive policies and techniques for accelerating the digitalization of the V4 economies. The study lists the pain points of the V4 digitalization and makes suggestions on recoveries, mainly on the field of the potential involvement of companies and the financing of the national 140 platforms.
\end{abstract}

Keywords: Visegrad Four; digital transformation; digitalization; Industry 4.0 JEL classification: O11, O14, O23, O38, O33, D83.

\section{Introduction}

Digital transformation impacts every segment of the economy and society. Added value, trained workforce and relocated industry become the most important benchmarks in the competition between nations. New technologies will result in new business structures, new products, new operating models and digital networks at the micro level in the next two decades, coupled with efficient paperless states, shifting status quos and changing economic rules applicable in the macro economy

\footnotetext{
* Corresponding author. Address: Doctoral School of Regional- and Business Administration Sciences, Széchenyi University, Hungary, 9026 Győr, Egyetem tér 1., gyimesi.aron@yahoo.com
} 
(Kagermann et al. 2013; Klitou et al. 2017c; Morrar et al. 2017; Blanchet et al. 2014; Giesbauer et al. 2016). Just like all other European states and the top bodies of the European Union, the Visegrad Four (V4) countries respond to this challenge as it is represented by the Digital Transformation Monitor (DTM) published by the European Committee (EC) (Klitou et al. 2018a; Klitou et al. 2017b; Klitou et al. 2017a; Klitou et al. 2018b). Digitalization, as a complex multi-dimensional and multi-disciplinary issue, is regarded as one of the most important economic policy and geopolitical issues (Kagermann et al. 2016).

The study uses word "digitalization" in the meaning of national digital developments for rising efficiency on macroeconomic level, meanwhile word "digital transformation" or Industry 4.0 (140) will be used on the corporate level referring to the process reengineering achievements by the digital technologies.

For having an impulse on the readiness level of a specific country, digitalization indexes are considered important sources. These scales make the detailed evaluation and the comparative analysis possible. The V4 countries - Czech Republic, Hungary, Poland, Slovakia - have reached similar results and faced with similar constraints regarding digitalization. The countries are at a pretty similar digitalization level according to the DESI (Digital Economy and Society Index) rankings, although placed at the inglorious last third segment of the lists (EC 2020d). The relevant indexes and their scorings will be presented in the first half of the study as well as the specific digitalization context of the V4 countries and their economies, showing the structural issues regarding digitalization they have to deal with financing, education, knowledge transfer, legislation, and innovation (Grzyb 2019; Mattauch 2017; Grencikova et al. 2020; Johanesova et al. 2019; Nick et al. 2017).

The second part of the study is about the national 140 platforms (frameworks) that represent the strategic and economic policies of the industrial digital transformation. The national 140 platforms have an intermediary role. These institutions link the policy makers and the company segment by initiatives, fundings, professional services, consultancy services, expertise, promotions, and support for digital developments. These platforms take part in training SMEs, bringing together stakeholders, and opening labs (Probst et al 2017). The national 140 platforms have a direct role to support the digital transition, solving the structural issues of the national economies and accelerate adoption of digital transformation at the corporate level.

The study makes a comparative analysis of the 140 platforms of the V4 countries. The analysis is extended by three of the Frontrunner countries of the EU Austria, Germany, and Sweden - in the field of digitalization as well (Nick et al. 2019b). The comparison leads to the main findings of the paper, based on the similarities and differences of the policies applied, highlighted the lessons to be learned from the Frontrunners. Ideas will be added for finetuning the set of policies, initiatives and actions of the national 140 platforms in the V4 countries in the closing chapters, for further discussions.

\section{Literature review}

The idea of comparative analysis of contuntries along with international rankings, and EU level statistics already resulted relevant scientific findings regarding the CEE region. 
Moroz (2017), for instance, visualized the DESI sub-categories by putting the layers on each other, and making a comparison of five EU countries including Poland, Slovakia, Germany, Lithuania, Italy. Moroz (2017) urged immediate actions for Poland to boost the ICT impact on the economy, seeing the gap between the achievements of digital transformation of the revised set of countries and Poland.

Grzyb compared Polish companies with the EU average, and the EU digital leaders referring to the adopted 140 technologies. The study also emphasized the Polish backlogs in values (Grzyb 2019).

Papula et al. (2017) show a comparison by industry segments, comparing the Slovak 140 preparations with the Austrian, German and Swiss achievements. The research presented significant level of backlog on one hand, and rapid development on the other. Slovakia has made huge steps in digital development, mainly on the backbone level infrastructure on a yearly basis, and has faced the lack of relevant competences and human resources (Papula et al. 2017).

Ulewicz et al. (2019) carried out the research on Poland and Slovakia, demonstrating that providing financial support for SMEs was crucial to achieve results in penetration of the digital transformation.

The study aims to make a comparative analysis that is different compared to the ones mentioned above, mainly in its approach. The comparison of the paper is based on the national 140 platforms specifically, expecting new, jet unrevealed conclusions.

\section{Research methodology and hypotesises}

The methodology of the research is based on the EU level DTM publications on the national 140 platforms (Klitou et al. 2018a; Klitou et al. 2017b; Klitou et al. 2017a; Klitou et al. 2018b). During the research work the most important attributes of the national 140 platforms were put next to each other by the country reports of the V4 and the Frontrunner countries. The aggregation and the comparison of the data led to a new set of information and the conclusions. The idea of the extraction of data from the DTM publications was activity led. It means that activities executed and planned by the national 140 platforms were put into the comparison tables. The selection covers different levels of fields of activities, 11 segments in total.

The resulting table involves strategic planning activities, policies, initiatives as well as direct tasks (ie. 140 campaigns, exhibitions, education). The table makes possible of grouping along with different views. One of the views applied refers to the V4 countries as a group, and the Frontrunners as another.

The hypothesis formulated is (H1): Good practices applied by the Frontrunner countries regarding digitalization differ from the practices of the national 140 platforms of the V4 countries. The expectation is to reveal explanatory differences that need to be taken into consideration by the V4 countries, regardless of the other relevant economic conditions.

The second hypothesis (H2) is: The V4 countries apply similar toolset of 140 policies. The expectation is to reveal relevant similarities due to their homologous status of digitalization and digital transformation. 


\section{4. $\mathbf{1 4 0}$ readiness and the Digitalization status of the $\mathbf{V} \mathbf{4}$ countries}

Since the last decade, the V4 countries have reached a significant economic growth and a substantial industrial development. The average annual GDP growth of the four economies is between $3.0 \%$ and $4.8 \%$, with a high contribution of the industry sector of approximately $30 \%$. The highest added value has been achieved by the Czech industry. The GDP growth is driven by the export and also by domestic consumption. There is a strong dominance of SMEs in all of the examined industries even in the priority manufacturing sectors, such as the 1. car industry, 2 . electronics, 3. pharmaceuticals, 4. IT\&C. However, the level of labour efficiency is low in all of the four industries. The labour market shows the symptoms of saturation, with growing wages, while growth is coupled with the increase of imports (EC 2019a; EC 2019b; EC 2019c; EC 2019d; Adamek 2018; Mattauch 2017; Nick et al. 2019a).

The V4 countries (except Poland) constitute a characteristic group representing Traditional Industry by categorization of Roland Berger international consulting firm, regarding the 140 readiness (Hoff 2016). These countries are characterized by a significant level of industrial activities, however, their technological and digitalization level is considered underdeveloped. The industrial structure is based on assembling activity with low level of added value, limited innovation, and low-rate research and development. By way of contrast, Frontrunners are characterized by a high technological level, high added value and high-rate industrial output.

At the same time, the industrial tradition in these countries is significant and long-standing. Therefore, it is no coincidence that this region, following the change of regime, has been strongly linked to automotive manufacturing, the number one industrial supply and production chain of our time, making use of the advantage provided by the wage arbitrage. Nowadays, the V4 countries have strong ties with the German multinational car manufacturing holdings (Csíki et al. 2019).

The EC (the European Commission) ranks the digital readiness of the countries within the EU on the basis of the DESI Index. The DESI Index is a composite index, suitable for quantification of the digital readiness of the countries. The index analyses five strategic areas: 1. Connectivity - access to broadband; 2. Human capital / Digital skills; 3. Use of Internet services (population); 4. Integration of digital technology (business); 5 . Digital public services. ${ }^{1}$ The DESI index monitors the elements and the rate of development (EC 2017). The DESI index, measures digitalization as a social challenge for business as a whole, cumulatively. The DESI index is published by the EU annually (Losonczi et al. 2019).

The rankings of the V4 countries are close to each other on the basis of the DESI index, meaning that the four countries have a very similar level of development in digitalization, see Figure 1 (EC 2020d). Nevertheless, all the four countries are located in the last third of the list. Their results at the measured individual strategical areas are typically attain below the average or spread evenly through the EU average values.

\footnotetext{
${ }^{1}$ https://ec.europa.eu/digital-single-market/en/news/digital-economy-and-society-indexdesi-2020
} 
Fig. 2: DESI index 2020 ranking

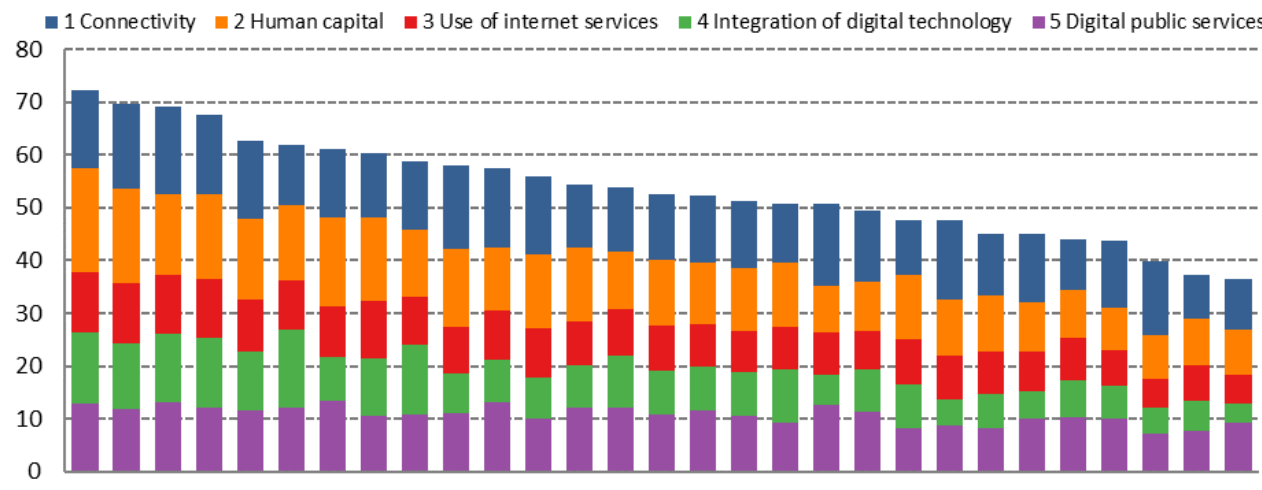

FI SE DK NL MT IE EE UK BE LU ES DE AT LT EU FR SI CZ LV PT HR HU SK PL CY IT RO EL BG

Source: DESI Country Report Hungary 2020 (EC 2020d)

It is interesting to observe that the Frontrunners of the Roland Berger classification method have different rankings compared to DESI, due to the different contexts of the measured elements. The German and the Austrian economies are positioned in the middle of the field, while Sweden achieved the top ranking in this comparison. The summary of the ranking (Table 1), made based on the 2014-2020 DESI index, demonstrates the traces of competition among the countries through the changes in their ranking. Of the V4 countries, the Czech Republic boasts the most developed digitalization status, overtaking the other three countries by 2-3 places. The Czech Republic can be found above the EU average values in the majority of the reviewed aspects, while the other V4 countries are slightly lagging behind (EC 2017, EC 2018a, EC 2019a, EC2020a EC 2020a, EC2020b, EC 2020c, EC 2020d).

Table 1: Position of selected countries in DESI, 2014-2020

\begin{tabular}{|c|c|c|c|c|c|c|c|c|c|}
\hline No. & 2014 & No. & 2017 & No. & 2018 & No. & 2019 & No. & 2020 \\
\hline 1 & Denmark & 1 & Denmark & 1 & Sweden & 1 & Finland & 1 & Finland \\
\hline 2 & Sweden & 2 & Finland & 2 & Finland & 2 & Sweden & 2 & Sweden \\
\hline 3 & Finland & 3 & Sweden & 3 & Denmark & 3 & Dánia & 3 & Denmark \\
\hline 10 & Germany & 11 & Austria & 13 & Austria & 13 & Germany & 12 & Germany \\
\hline 11 & Austria & 14 & Germany & 14 & Germany & 14 & Austria & 13 & Austria \\
\hline 19 & Czech Republic & 17 & Czech Republic & 19 & Czech Republic & 18 & Czech Republic & 17 & Czech Republic \\
\hline 20 & Slovakia & 20 & Slovakia & 20 & Slovakia & 21 & Slovakia & 21 & Hungary \\
\hline 21 & Hungary & 22 & Hungary & 22 & Hungary & 22 & Hungary & 22 & Slovakia \\
\hline 22 & Poland & 24 & Poland & 24 & Poland & 25 & Poland & 23 & Poland \\
\hline 28 & Romania & 28 & Romania & 28 & Greece & 28 & Bulgaria & 28 & Bulgaria \\
\hline
\end{tabular}

Source: Own compilation, based on DESI database reports and DESI country reports 2014-2020 (EC 2017, EC 2018a, EC 2019a, EC2020a EC 2020a, EC2020b, EC 2020c, EC 2020d)

It seems that the V4 countries stick together not only on the geopolitical level, but on the economic development level as well. They follow a fairly similar digitalization path. 


\section{Four countries, four different level of digitalization achieved}

\subsection{Czech Republic}

According to the DESI index, the Czech Republic is ahead of the other V4 countries in digital development, and belongs to the moderately developed countries on the basis of several factors, reaching or going above the EU28 averages (DESI 2018a).

The presence of 140 in businesses varies significantly. It is the highest in the automotive industry, electrical engineering and pharmaceutical industry. Strategic priorities are outlined in the Czech Digital Agenda / Digital Czech Republic (2018) framework: 1. Supporting digital and technological innovation, 2. Stimulating entrepreneurship, 3. Providing easier conditions for access to capital, 4. Adopting future-proof regulations, 5 . Building the competences and skills of the future. The Society 4.0 initiative is also present in the policies, putting emphasis on surveying and managing the impacts of 140 not only in the strictly interpreted industrial production, but also in education, in the labour market and in other segments (Adamek 2018). The Digital Czech Republic is linked with the Industry 4.0 Strategy, launched in 2016.

Based on the research carried out by Vrchota and Pech, $62 \%$ of the companies in the Czech Republic consider themselves to be impacted by the 140 paradigm, and this confirms the $65 \%$ rate measured by the Czech Chamber of Industry. The degree of awareness-raising and the importance of digital transformation, together with the statistically detectable adaptation readiness level, increases in line with the size of the company (Vrchota - Pech 2019).

\subsection{Hungary}

Regarding its digitalization readiness level, Hungary, based on the DESI index, also belongs to the last third of the EU28 countries. Hungary has shown a developing trend in recent years, catching up with a development rate above the EU average. (EC 2020d). The highest scores are achieved in the broadband internet access, while the country underperforms in the fields of digital public services and the integration of digital technologies.

Strengthening the technological adaptation and accelerating the digitalization is an important task for the future competitiveness of Hungary. Regarding the latter, it is indispensable to employ skilled workforce and to change the economic model accordingly: to switch to an economy which focuses on added value (Losonci et al. 2019). Hungary's digitalization strategy is the Digital Welfare Program (2015) which, in addition to the possibility of applying new technologies, defines specific strategic orientations for education, start-up businesses and various branches of industry (EC 2019d).

The level of digitalization of SMEs in the business sector is low due to the limited capital available for them for the implementation of developments (EC 2019d), while the lack of skills is also a significant deficit (Nick et al. 2017).

Companies in Hungary are open to meet the requirements of digital transformation: $71 \%$ of the companies consider 140 important from the point of view of their competitiveness, however, the majority of them 1. do not have a suitable strategy, 2. do not consider vertical integration important, 3. have poor innovation related experience, and 4. have only limited real-life experience (Nick et al. 2017). 
Based on the preliminary results of an already not published scientific research of the authors own, further interesting conclusions can be added to the knowledge about the digitalization awareness of the corporate sector in Hungary. The country wide primer research was addressed 3000 mainly SME companies and resulted $100+$ fully filled forms answering the 71 questions total. The questionnaire was carried out at the turn of 2020-2021. See highlighted results relevant in the followings: $1.41 \%$ of companies consider it particularly important to prepare for the digital transformation, with the contradiction, however, that 2.) $54 \%$ of companies believe that the pressure of digital transformation is less valid for them. 3.) $50 \%$ of respondents believe that they will be ready for the challenges of digital transformation in $2-3$ years (as compared to the current $25 \%$ ).

\subsection{Poland}

Significant developments have been carried out by the country to facilitate the digitization transition, primarily in building a broadband internet infrastructure (EC 2019b). However, the integration of efficiency-increasing technologies is below the EU average (Weresa - Kowalsky 2019). Poland has been developing continuously, both in terms of Internet technologies and human resources (EC 2018b). Nevertheless, the digitization level of the companies continues to be low, with $60 \%$ having a low digitization value (EC 2019b).

The digitization strategy of the country is the Responsible Development Program which sets the target of re-industrializing the country within the framework of several sub-programs (including the Future Industry Program, the sub-program of which is Industry 4.0 / Przemysl 4.0, see later). The program is a 25-year strategy intended to re-position the country (Morawiecki plan). The Smart Growth Program, aimed at strengthening innovation, research and competitiveness, also supports digitalization (EC 2019b).

The country is intentionally digitalizing public administration (Paperless Poland), occasionally applying blockchain and Al technologies. Another positive development is the increase in the number of start-up businesses $(+4 \%-2016-2017)$.

For the Polish companies, transfer of the 140 knowledge seems really important, ensuring that the investments they launched provide adequate returns (Grzyb 2019). It also appears from Grzyb's research that among Polish companies the highest demand for 140 solutions can be detected predominantly in the following branches of industry: vehicle industry (93\%), manufacturing industry (45\%) and pharmaceuticals (35\%). SMEs are seemingly excluded from the transformation process; only $42 \%$ of the participants in the research gave the response that they are addressing the issue of digital transformation. 140 is considered by the vast majority of the interviewed companies as a tool for improving efficiency, and $48 \%$ thought that it can also be applied as a customer satisfaction improvement tool (Grzyb 2019). $40 \%$ of the Polish companies see business possibilities in disseminating digital transformation as a paradigm, and $87 \%$ stated that a slightly increasing demand could be witnessed in the market for smart products, as compared to past years (Grzyb 2019).

\subsection{Slovakia}

Slovakia also underperforms in terms of its level of digitalization, similarly to the other V4 countries. For Slovakia, it is access to broadband Internet and digital public services (EC 2019a). Based on the DESI index, access to broadband Internet 
and the $4 \mathrm{G}$ access are below the EU average, just as the digital skills of the population. Slovakia did not present any significant development in digitalization, according to the DESI index (EC 2020a).

The Slovak companies underperform in research and development. This constitutes a barrier to activities with higher added value. Therefore, it is essential for education to meet the demand coming from the fields of ICT and engineering.

The Slovak Smart Industry / Industry 4.0 strategy was launched in 2016, taking into account 35 aspects. Key points of the strategy are embedding the key branches of industry, promoting the economy via research, development and sciences, building an innovative society and developing skilled human resources (EC 2019a). The digital transformation is hindered by the lack of regulation, governmental guidance and subsidies. However, there are a number of initiatives providing assistance in intercompany cooperation (EC 2019a).

In 2018,50\% of the companies in Slovakia started to apply the 140 concept and that of smart technologies, according to the research conducted by Grencikova et al. (2020). However, there was a big leap in 2019: a positive response was given to this question by $84.5 \%$ of large corporations and $71 \%$ of medium-sized companies, while $62.4 \%$ of small companies and $39 \%$ of family businesses did not give a positive response to the question. 140 for the Slovak companies will first of all result in improving efficiency and reducing costs (Grencikova et al. 2020).

\section{National strategies and 140 platforms for the digitalization and the digital transformation of the industres}

In this chapter the importance of the national 140 platforms will be introduced. The national digitalization strategies and the national 140 platform initiatives will be examined more thoroughly.

The national 140 platforms are strongly connected to the EU2020 Strategy thorough several layers of EU and national level policy making bodies, initiatives and actions. Top-down and bottom-up effects must be parallelly and simultaneously maintained for strategic, harmonization and bureaucratic reasons. "A pyramid-model emerges by layering the initiatives, well representing the successive programs and their connections" (Nick et al. 2019a 35-36).

The "Europe 2020" strategy can be found at the very top of the system. The strategy intends to provide long-term, sustainable answers to the changes in the global economy, in accordance with the following fundamental criteria: 1. employment, 2. R\&D, 3. energy/climate, 4. education and 5. decrease of poverty. This will be built up and supplemented by "Seven Flagship Initiatives" from the viewpoint of economic development and competitiveness.

In 2015, the European Union launched the Digital Single Market (DSM) initiative aimed to remove the online barriers in the EU28 countries and create the Single Market. The targets of the initiative included the following: 1. fast connectivity, 2. protection of the private sector, 3 . building and securing new internet access modes. The initiative intends to build an adequate digital environment for SMEs and to create the opportunity for the population to develop the necessary new skills. "DSM examines the strategic break-out points of digitalization. The EC priorities are tangible economic aspects, and thus strengthening competitiveness, encouraging innovation and popularising sustainable business models are considered important factors. Great emphasis is placed on provision of resources to companies in terms of finances, skilled workforce, energy and raw materials" (Nick et al. 2019a 36). 
The Digitising Europe Industry (DEI) strategy, the first initiative focusing on industry, was introduced in 2016 under the umbrella of the DSM. In a way that complements national digitalization strategies, the DEI focuses on increasing the competitiveness of the EU and realizing the advantages of the 140. The DEI is built on five pillars. The pillars comprise comprehensive programs, initiatives, actions and workflows with a multi-disciplinary and comprehensive approach: 1. European platform of national initiatives in digital industry: 2. Digital Innovation Hubs; 3. regulatory framework suitable for the digital age, 4. preparing Europeans for the digital future and 5. strengthening leadership through partnerships and industrial platforms (EC 2017).

Digitalization of the continent is coordinated by the EC in accordance with the above strategies which extend to the community and national initiatives and serve as the catalysis of cooperation of governments driven by the EC policies (CENFIM 2018). National platforms join the strategic platforms from below (Buica 2016). These programs involve financing applications, awareness-raising initiatives and regional programs, focusing mainly on coordination and support of the digital transformation of industry (140), as one of the many areas of digital transformation. The toolsets of the 140 platforms (or frameworks) have an enormous impact on the moods and results of the national digital transformations.

\section{The national 140 platforms of the V4 countries}

\subsection{Czech Republic (Industry 4.0)}

The Czech Republic 140 initiative's vision is a fully digitalized industry. Innovation, scientific activity and support of research and development have a strong focus among the programs, including through financing of clusters, innovation centres and incubators. Companies can submit applications for building data centres and implementing software developments. Skills upgrading (Education 4.0) and applied research are in the focus of the program (Klitou et al. 2017a). Strategic priorities are outlined in the Czech Digital Agenda / Digital Czech Republic (2018) framework: 1. supporting digital and technological innovation, 2. stimulating entrepreneurship, 3. providing easier conditions for access to capital, 4. adopting future-proof regulations, 5. building the competences and skills of the future. The Society 4.0 initiative is also present in the policies, giving emphasis to surveying and managing the impacts of 140 not only in strictly interpreted industrial production, but also in education, in the labour market and in other segments (Adamek 2018). The Digital Czech Republic is linked with the Industry 4.0 Strategy, launched in 2016. Among strategic documents, it is also worth mentioning the Innovation Strategy and the Smart Specialisation Strategy. Central elements of the documents are innovation, R\&D, and efficiency (EC 2020c).

\subsection{Hungary (Industry 4.0 National Platform)}

The targets of the Industry 4.0 National Platform include 1. increasing industrial output, 2. promotion of R\&D, 3. innovation and 4. exports for domestic companies, 5. decreasing work activities that are performed by low-skilled workforce and dissemination of activities that require high qualifications. The strategic document aimed at following the methodology of the German Industry 4.0 initiative seeks to establish a balance between private and state actors regarding financing and involvement. Seven working groups have been formed within the framework of the 
platform with the aim of putting forward proposals for turning the principles into practical steps. The platform envisages strengthening the competitiveness of the country and increasing individual values of the companies by the implementation of digitalization and the 140 technologies. The initiative supports and emphasizes the importance of cooperation between stakeholders (Klitou et al. 2018a).

\subsection{Poland (Industry of the Future Platform)}

The Industry of the Future program plays the role of accelerator in industrial digitalization, supporting coordination between stakeholders. The ideas of the platform stem from the corporate sector. The primary aim is increasing the country's competitiveness. In the interest of this aim, the platform has created, among others, 1. a framework system related to professional skills, 2. promotion of the shift in paradigm has been started, 3. new business models have been drawn up and 4. integrated hw-sw solutions presented. Financing is provided by the state. The established working groups are involved in developing standards, substantiating the legal background and participating in educational and training issues, as well as in the promotion of developing 140 solutions (Klitou et al. 2017b).

\subsection{Slovakia (Smart industry)}

The primary promoter of the Slovak Smart Industry Initiative is the government of Slovakia. The aim of the initiative is catalysation of the digital development, predominantly on a technological basis, reacting simultaneously to the challenges of R\&D, the labour market and education. The initiative does not anticipate a decrease of labour in the industry, but it does anticipate a transformation of expected competences. 1. Knowledge transfer, 2. development of production and 3. availability of financing play an important role as well. The Slovak 140 digitalization model also significantly relies on participation and cooperation of stakeholders. In addition to developing the priorities of digitalization, the platform is involved in working out and implementing action plans (Klitou et al. 2018b). The Slovak Smart Industry / Industry 4.0 strategy was launched in 2016, taking into account 35 aspects. Key points of the strategy are embedding the key branches of industry, promoting the economy via research, development and sciences, building an innovative society and developing skilled human resources (EC 2019a). The transformation is hindered by the lack of regulation, governmental guidance and subsidies. However, there is a number of initiatives providing assistance in inter-company cooperation (EC 2019a).

\section{Comparison of the digitalization platform initiatives}

In order to make a detailed analysis of the 140 platforms, the DTM Country Monitor publications were compared during the research. The DTM specifies twelve aspects for the direct characterisation of the national 140 strategies and platforms, of which seven have been organised in a chart (1-7) in Table 2, while further four dimensions have been selected and highlighted by the author within the research activities, based on the reports. The table contains the characterisation of the three Frontrunner countries according to Roland Berger's 140 (Austria, Germany and Sweden) next to the V4 countries, focusing on industrial digitalization, governmental and national 140 approaches, principal directions, actions and deficits. 


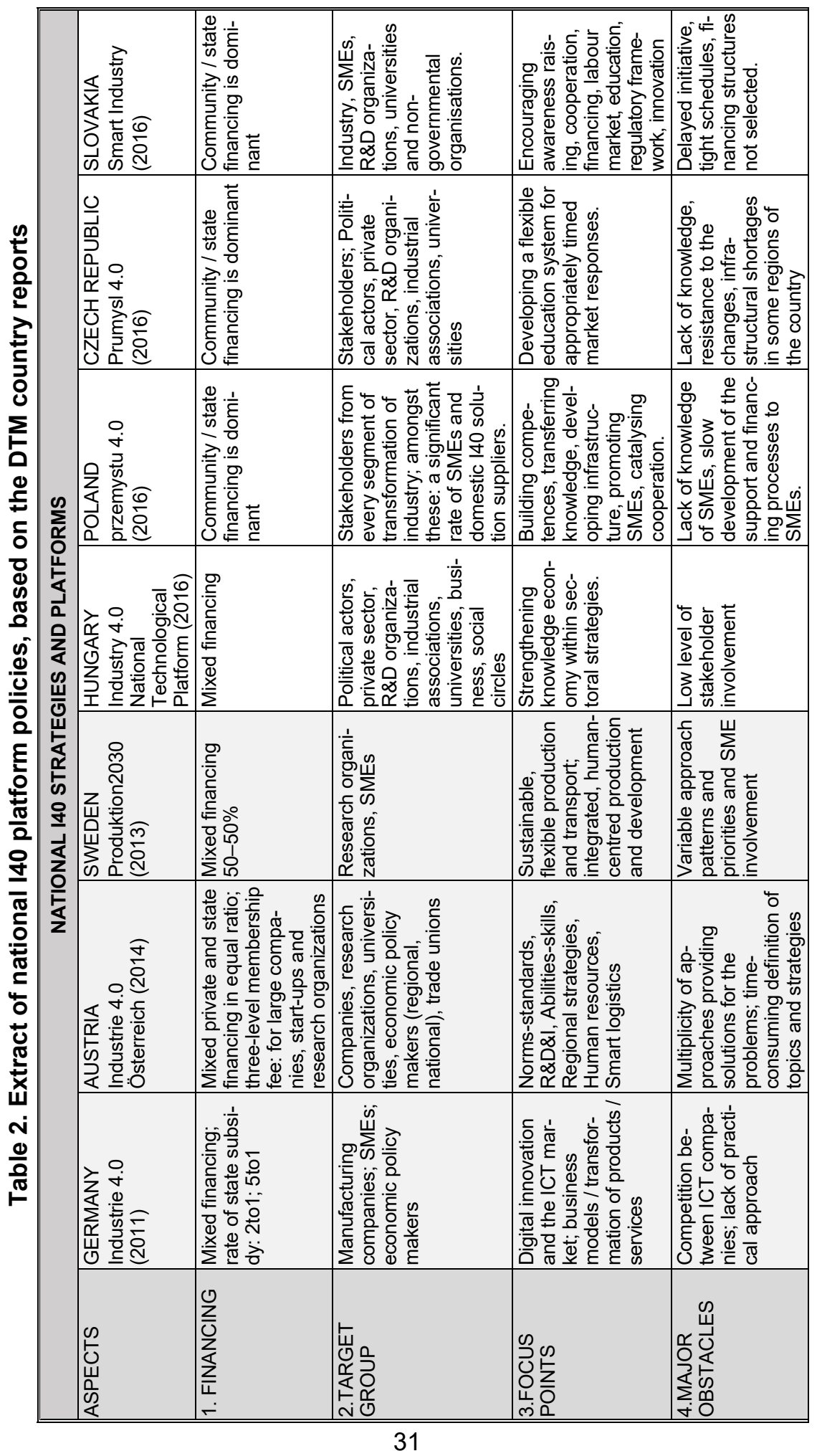




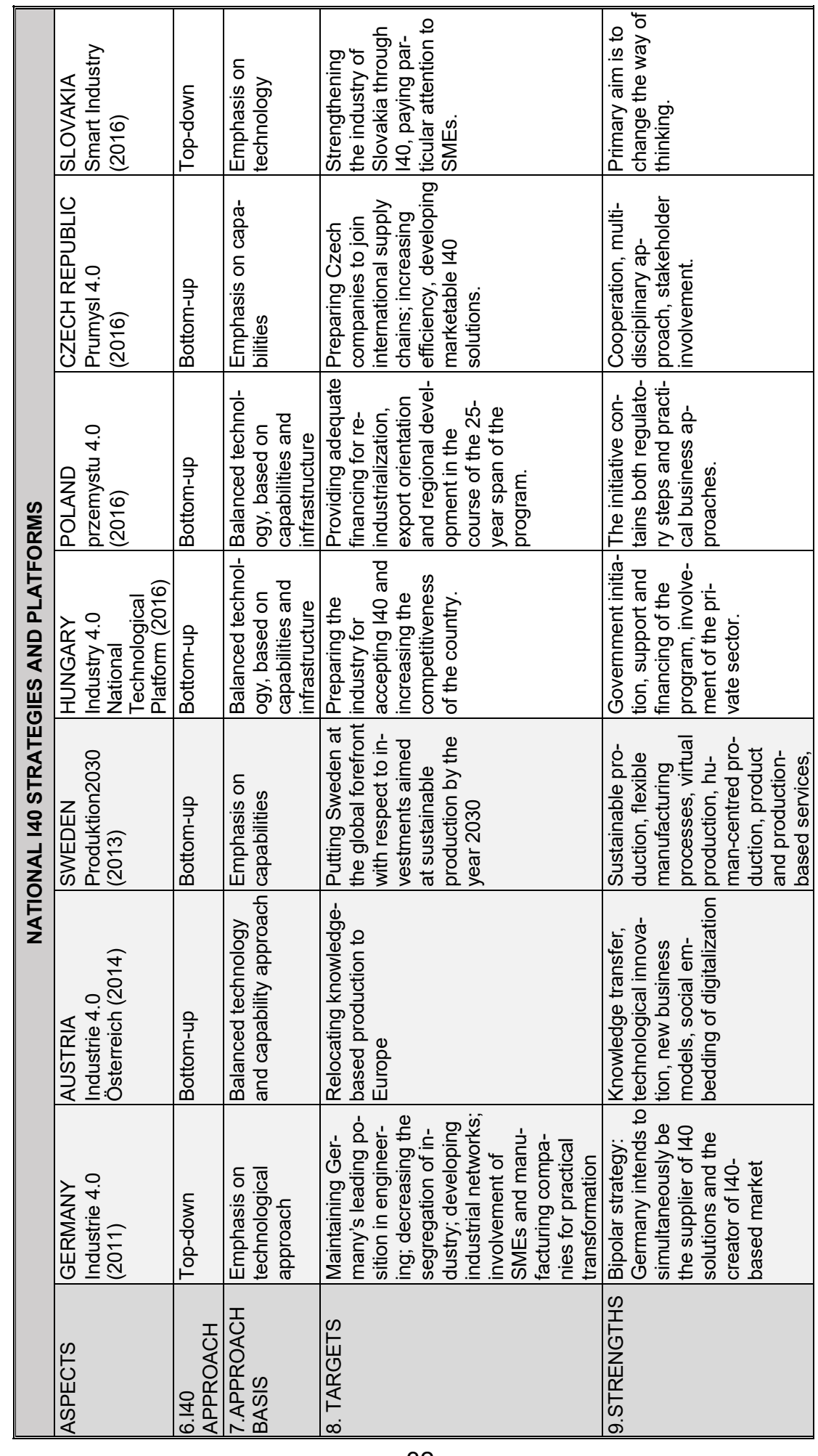




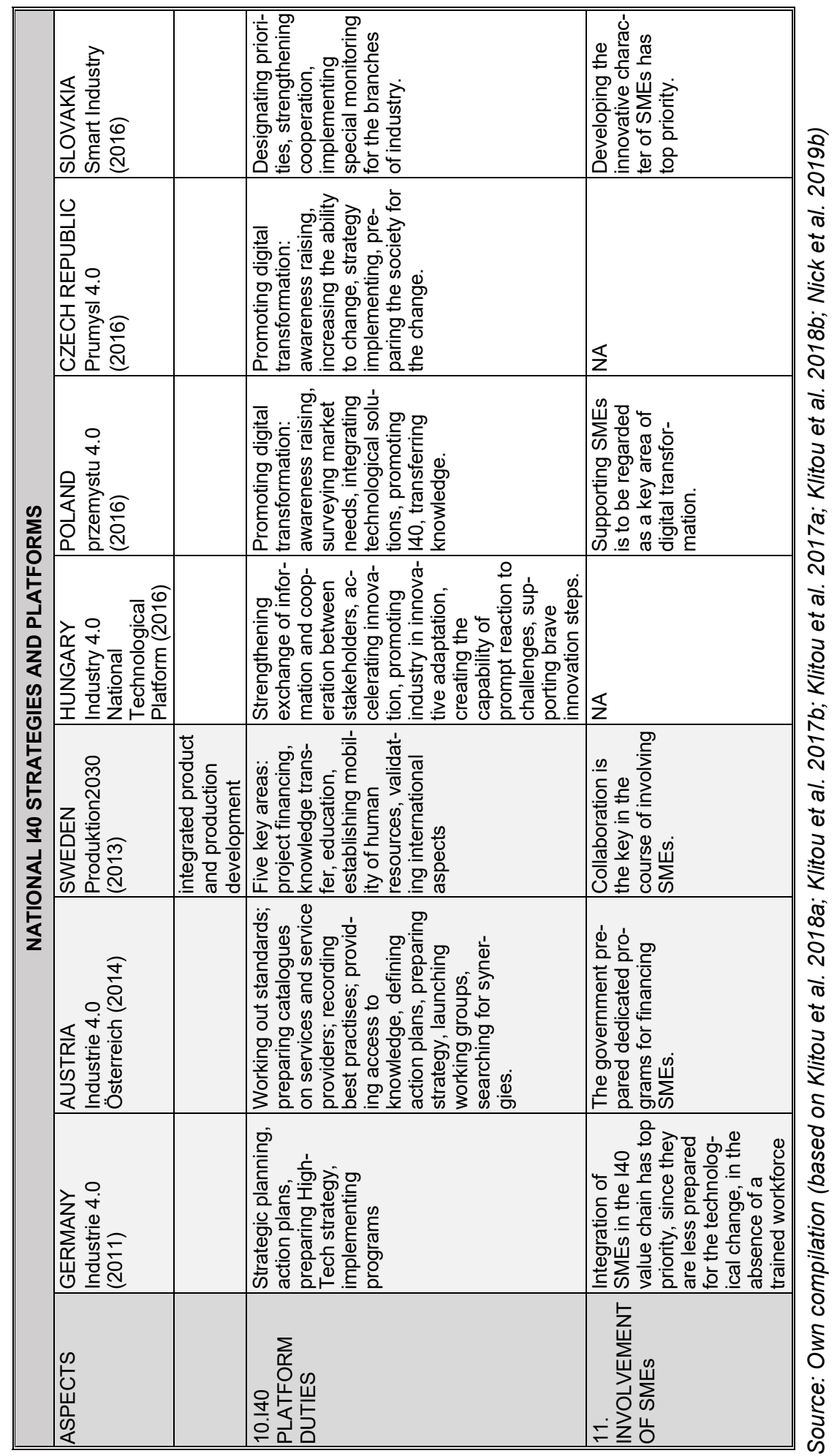




\section{Discussion and lessons learned}

Nick et al. (2019b: 48) contained a detailed analysis of the national 140 platforms of the three selected Frontrunner countries (Austria, Germany, Sweden). The summary of the similarities is shown below. "The factors assessed at strategic level show clear-cut similarities:

- Community / mixed financing on the part of the state / entrepreneurs,

- Targeted development and involvement of SMEs,

- Strengthening R\&D\&I,

- Cooperation of the state and the entrepreneur/academic sectors,

- Developing digital capabilities,

- Bottom-up "build-up",

- Innovative market initiatives for establishing faster and more efficient implementation and raising interest."

Along with the current research the comparative analysis is performed for the $\mathrm{V} 4$ countries also.

Regarding the national 140 platforms of the V4 countries, the following observations can be made, adding a counterpoint to the Frontrunners, where relevant:

- Financing is based on community (state) resources in all four countries, in contrast with the mixed financing of the Frontrunners;

- There is a need for the presence and development of knowledge and competence, similarly to the Frontrunners;

- There is a typical bottom-up structure in the V4 countries, similarly to the Frontrunners;

- The approach of digitalization is based on technology and capability, in a balanced manner (although to a different extent in the altogether seven analysed countries);

- The targets are consistent: 1. relocating industry, 2. increasing added value, 3 . strengthening competitiveness, 4 . cooperation of stakeholders, and the 5 . need for R\&D. These are given priorities in each country, Frontrunners and V4 countries alike;

- The involvement of SMEs in the national digitalization is detected as high priority endeavour to all of the V4 countries, just like the Frontrunners.

Having the answers to the key questions of the study, we can state that there are similarities in the national 140 platforms of the V4 countries. Most of the territories of the frameworks are managed similarly, inclusive financing, structuring, and approaching, as detailed above - justifying $\mathrm{H} 2$.

As for the key differences, compared to the Frontrunner countries, the way of financing can be mentioned. Meanwhile the community (state) financing is typical in the V4 countries, the mixed financing is available in the Frontrunner ones - justifying $\mathrm{H} 1$.

The results may explain the findings of the authors referred within the literature review (Moroz 2017; Grzyb 2019; Papula et al.; 2017 Ulewicz et al. 2019). They detect the low level of progress and involvement of the companies, regarding the 140 in the V4 countries. It seems that the community / state financing of the national 140 platforms and initiatives does not foster the company level digital transformation 
buy-in well enough. Mixed financing - on the other hand - may power the involvement and the commitment of companies (including SMEs) in many ways. It might be a valid proposal for companies to take part in financing of the national 140 platform also, at least at an indirect way, for example purchasing relevant services.

The companies in the V4 countries see inadequate their 1. financial possibilities, 2. skilled competences, 3. level of involvement, and 4. level of awareness (Mattauch 2017; Johanesova et al. 2019; Grzyb 2019). They also face with other constraints: 1. weak start-up ecosystem, 2. weak productivity, 3. low-level personal skills, 4. slow adaptation, 5. low-level demand for learning, 6. effects of the brain-drain, 7. low level of automation, 8. low-rate ICT investments, 9. barriers to international growth, 10. lack of regional cooperation, 11. weak innovation, 12. low level of digital public services (Novak et al., 2018, a, b, c).

The national 140 platforms should put a bigger emphasis on attracting and addressing companies, by answering their constraints above. The bottom-up need for company level digital transformation must be invoked, and the cooperation with the governmental bodies should be strengthened. Fulfilling that need, additional direct actions should be formed, based on mixed financing:

- Dedicated promotions are needed

- Dedicated financial programs are needed

- Knowledge transfer should be available

- Champions program are welcome

- ICT and start-up programs should be linked to the 140 programs

- Learning paths are welcome

- Bottom-up surveys should be designed and published

- $\mathrm{RnD}$ and innovation must be emphasized

- $\quad 140$ consultancy services should be addressed

- Crowdfundig Platform may be useful

- $\quad$ Shared licensing, shared know-how may help investments

\section{Conclusion}

The real risk for the V4 countries is that they will lose ground in the digital transformation. Their economies which are based on low labour costs are becoming less attractive to developed countries day-by-day. The 140 solutions of the developed countries result in increased efficiency, therefore developing economies are indirectly devalued and they are marginalised compared to the developed ones (Ulewicz et al. 2019). The danger of marginalisation derives from the basic philosophy of 140 itself: in the long run, machines will perform repetitive activities instead of humans. Therefore, the companies of the V4 countries have to move towards higher added value. This, however, first of all requires skills and competences and, naturally, a large number of other digital transformation related external and internal technology, business, government and regulations related factors (Ulewicz et al. 2019).

The digitalization status of the V4 countries is fairly similar. Regarding the level of digitalization development, all four countries are members of the group of followers, lagging behind, according to DESI. This is certainly explained by the 1. similar industrial, 2. cultural and political heritage, 3. the similarity of the sizes and 4 . the open 
nature of their economies and evidently the 5. unification impact of EU strategies, programs and financing structures.

Naturally, the V4 countries are not identical indeed in terms of their digitalization level and set of features. The acceptance of digitalization becomes stronger in all four countries year-to-year, the number of company-level projects is increasing and the development of the countries can be detected in most measured aspects (EC 2018a; EC 2018b; EC 2019a; EC2019b).

Having a focus on the national 140 platform initiatives of the V4 countries, we can make a conclusion that the 140 platform initiatives are based on similar structures and policies - answering to $\mathrm{H} 2$ of the study. The state finance occurs in all the four countries that differ from the national 140 platform initiatives of the Frontrunner countries. Frontrunners have a mixed financing that catalyses adaption, involvement and commitment of the companies - answering to $\mathrm{H} 1$ of the study.

Making a comparison with the obstacles of the Frontrunners, it seems that the actual bottlenecks in the Frontrunner countries are more sophisticated, higherlevel and more indirect, as a result of their existing status of development. The issues that the V4 countries face with present the core of the digitalization and digital transformation. Lack of financing, knowledge, resources, awareness is detected as deficit.

Summarizing the findings of the research, relevant efforts should be put on promotion of the government programs, national digitalization strategies and national 140 platforms, thereby strengthening the innovation and digitalization level of the national economies. Catalysation and acceleration of digital transformation is a complex duty of the governmental bodies and the national 140 platforms, which they must break down to direct actions. The leaders of the countries should apply a mix of direct initiatives and policies, making it possible to catch up in the long term. The used policies should be attractive, supportive and also business-oriented (Ignatov, 2019). The Frontrunner countries in digitalization may provide good examples and practices for implementation.

The study definitely has limitations in a $360^{\circ}$ degrees economic overview of the national 140 environments. The paper focuses solely on the national 140 platform initiatives. The conclusions though, bring a specific view that could become a target of further research. The possible effects of modifying the financial policy of the national 140 platforms would worth additional scientific investigations.

\section{References}

Adamek P. (2018) A Research Agenda of Industry 4.0 from the Cech Perspective. Intech, 21-39

Blanchet M., Rinn T., Von Thaden G., de Thieulloy F. (2014) Industry 4.0: The new industrial revolution - How Europe will Succeed. Roland Berger Strategy Consultants, Think Act, 3.

Buica M. (2016) New Industrial Policy or New Industrial Revolution for Increasing European Competitiveness? Journal of Business Economics and Information Technology, 2, 3, 8-19

CENFIM (2018) Map of initiatives supporting the implementation of Industry Digitalization in across the EU, European Committee 
Csíki O., Horváth R., Szász L. (2019) A Study of Regional-Level Location Factors of Car Manufacturing Companies in the EU. Acta Oeconomica, Vol. 69 (S2), 13-39

DESI (2018a) Digital Economy and Society Index (DESI), 2018 Country Report Czech Republic, Europeran Commission

EC (2017) DIGITISING EUROPEAN INDUSTRY, Europeran Commission

EC (2018b) Digital Economy and Society Index (DESI) 2018 Country Report Poland, Europeran Commission

EC (2019a) Monitoring Progress in National Initiatives on Digitalising Industry, Country report: Slovakia, Europeran Commission, VVA, VIK Consult

EC (2019b), Monitoring Progress in National Initiatives on Digitalising Industry, Country report: Poland, European Commission, VVA, VIK Consult

EC (2019c) Monitoring Progress in National Initiatives on Digitalising Industry, Country report: Czech Republic, European Commission, VVA, VIK Consult

EC (2019d) Monitoring Progress in National Initiatives on Digitalising Industry, Country report: Hungary, European Commission, VVA, VIK Consult

EC (2020a) Digital Economy and Society Index (DESI), 2020 Slovakia, Eureopean Commission

EC (2020c) Digital Economy and Society Index (DESI) 2020 Czech Republic, European Commission

EC (2020d) Digital Economy and Society Index (DESI) 2020 Hungary, European Commission

Geissbauer R., Vedso J., Schrauf S. (2016) Industry 4.0: Building the Digital Enterprise. - Global Industry 4.0 Survey, PWC

Grencíková A., Kordoš M., Berkovic V. (2020) The Impact of Industry 4.0 on Jobs Creation within the Small and Medium-Sized Enterprises and Family Businesses in Slovakia. Administratrive Sciences, 2020, 10, 71; 1-20

Grzyb K. (2019) Industry 4.0 Market in Poland from the International Perspective. Hradec Economic Days Vol. 9(1), 2019 February 5-6, 2019 Hradec Králové, Czech Republic

Hoff P. (2016) Industry 4.0 - Challenge for the F\&B industry in Greece, advantage or competitive disadvantage. Roland Berger, Greece

Ignatov A. (2019) Institutional efficiency, entrepreneurship, and the premises of economic development in the Eastern European Countries. Studia Universitas Babes-Bolyai Oeconomica, Volume 64, Issue 2, 2019, 12-32

Johanesová V., Stupavská L., Vaňová J., Čambál M. (2019)

Linking Industry 4.0 and Slovak Republic. $30^{\text {th }}$ DAAAM International Symposium on Intelligent manufacturing and automation, B. Katalinic (Ed.), DAAAM International, Vienna, Austria, 1122-1130

Kagermann H., Anderl R., Gausemeier J., Schuh G. Wahlster W. (2016) Industrie 4.0 in a Global Context - Strategies for Cooperating with International Partners. acatech STUDY, Munich, Germany

Kagermann H., Wahlster W., Helbig J. (2013) Recommendations for implementing the strategic initiative INDUSTRIE 4.0. Secretariat of the Platform Industrie 4.0, Germany

Klitou D., Conrads J., Rasmussen M., Probst L., Pedersen B. (2017c) Key lessons from national industry 4.0 policy initiatives in Europe. Digital Transformation Monitor, PwC, CARSA, European Commission, EU 
Klitou D., Conrads J., Rasmussen M., Probst L., Pedersen B., Lefebvre V. (2017a) Czech Republic: Průmysl 4.0. Digital Transformation Monitor (DTM), European Commission, Directorate-General Internal Market, Industry, Entrepreneurship and SMEs; Directorate F: Innovation and Advanced Manufacturing; Unit F/3 KETs, Digital Manufacturing and Interoperability

Klitou D., Conrads J., Rasmussen M., Probst L., Pedersen B., Lefebvre V. (2017b) Poland: "Initiative for Polish Industry 4.0 - The Future Industry Platform". Digital Transformation Monitor (DTM), European Commission, Directorate-General Internal Market, Industry, Entrepreneurship and SMEs; Directorate F: Innovation and Advanced Manufacturing; Unit F/3 KETs, Digital Manufacturing and Interoperability

Klitou D., Conrads J., Rasmussen M., Probst L., Pedersen B., Lefebvre, V. (2018a) Hungary: "IPAR 4.0 National Technology Platform". Digital Transformation Monitor (DTM), European Commission, Directorate-General Internal Market, Industry, Entrepreneurship and SMEs; Directorate F: Innovation and Advanced Manufacturing; Unit F/3 KETs, Digital Manufacturing and Interoperability

Klitou D., Conrads J., Rasmussen M., Probst L., Pedersen B., Lefebvre, V. (2018b) Slovakia: Smart Industry. Digital Transformation Monitor (DTM), European Commission, Directorate-General Internal Market, Industry, Entrepreneurship and SMEs; Directorate F: Innovation and Advanced Manufacturing; Unit F/3 KETs, Digital Manufacturing and Interoperability

Losonci D., Takács O., Demeter K. (2019) Az ipar 4.0 hatásainak nyomában - a magyarországi járműipar elemzése. Közgazdasági Szemle, LXVI. évf., 2019. február, $185-218$

Mattauch W. (2017) Digitising European Industries -Member States Profile: Poland, European Committee

Moroz M. (2017) The level of development of digital economy in Poland and selected European Countries: a comparative analysis. Foundations of Management, Vol. 9 (2017), 175-190

Morrar R., Arman H., Mousa S. (2017) The Fourth Industrial Revolution (Industry 4.0): A Social Innovation Perspective. Technology Innovation Management Review November 2017 (Volume 7, Issue 11) 11-20

Nick G., Gallina V., Szaller Á., Várgedő T., Schumacher A. (2019a) Industry 4.0 in Germany, Austria and Hungary: interpretation, strategies and readiness models. 16th IMEKO TC10 Conference, Berlin, Germany, on September 3-4, 2019

Nick G., Gyimesi Á., Radács E. (2019b) Az Ipar 4.0 keretrendszerének bemutatása három élenjáró európai ország - Németország, Svédország és Ausztria stratégiái alapján. Tér-Gazdaság-Ember, 2019 VII. 1-2, 31-52

Nick G., Váncza J., Várgedő T. (2017) AZ IPAR 4.0 Nemzeti Technológiaiplatform Kérdőív Projekt. Ipar 4.0 Nemzeti Technológiai Platform Szövetség

Novak J., Purta M., Marciniak T., Ignatowicz K., Rozenbaum K., Yearwood K., Svoboda D., Skalsky M., Sarkanova H. (2018a) The Rise of Digital Challenges Perspecitve on Slovakia. McKinsey \& Company

Novak J., Purta M., Marciniak T., Ignatowicz K., Rozenbaum K., Yearwood K.; Svoboda D., Karalokev T., Skalsky M. (2018b) The Rise of Digital Challenges Perspecitve on Czech Republic. McKinsey \& Company

Novak J., Purta M., Marciniak T., Ignatowicz K., Rozenbaum K., Yearwood K. (2018c) The Rise of Digital Challenges - Perspecitve on Poland. McKinsey \& Company 
Papula J., Kohnová L., Papulová Z., Suchoba M. (2019) Industry 4.0: Preparation of Slovak Companies, the Comparative Study. Smart Technology Trends in Industrial and Business Management., Springer, 103-114

Probst L., Pedersen B., Lonkeu O-K., Martinez-Diaz C., Novelle Araujo L., Klitou, D., Conrads J., Rasmussen M. (2017) Evidence of positive outcomes and current opportunities for EU businesses. Digital Transformation Scoreboard, European Commission, European Union

Ulewicz R., Novy F. Sethanan K. (2019) The challenges of industry 4.0 for small and medium enterprises in Poland and Slokvakia. Quality Production Improvement, Volume 1, issue 1, 147-154

Vrchota J., Pech M. (2019) Readiness of Enterprises in Czech Republic to Implement Industry 4.0: Index of Industry 4.0. Applied Sciences 2019, 9, 1-25

Weresa M. A., Kowalski A. M. (2019) Poland competitiveness report 2019., International Competitiveness in the Context of Development of Industry 4.0., Collegium of World Economy, The World Economy Research Institute's International Seminar of Manufacturing and Services and International Competitiveness: National and Regional Perspectives, 11 October 2019, Warsaw, Poland 